\title{
A görkorcsolyázás története IV.
}

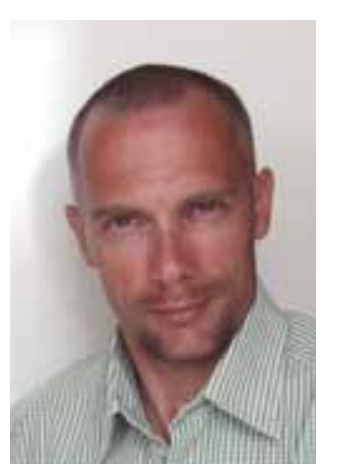

Szerző: DR. BÉRES SÁNDOR

egyetemi docens

Eszterházy Károly Főiskola

Sporttudományi Intézet

Eger

beres.sandor@ektf.hu

Összefoglalás: A görkorcsolyázás története $\mathrm{I}^{1}$., ${ } \mathrm{I}^{2}$., $\mathrm{II}^{3}$. című tanulmányban bemutattuk a görkorcsolya kialakulásának történetét az 1700-as évek közepétől az Olsen fivérek tevékenységével bezárólag. Jelen írásban foglalkozunk a 90-es évek görkorcsolya életével, a motoros görkorcsolyák elterjedésével, fajtáival. Bemutatunk néhány olyan új, kivételesen egyedi görkorcsolya tervet, melyek később divatot teremthetnek és az eszköz, e mozgásforma sokszínüségét képviselik. Végül egy rövid áttekintésben foglalkozunk a görkorcsolya „filmes" karrierjével is.

Kulcsszavak: görkorcsolya, görkorcsolyázás, egysoros, párhuzamos, történet

Abstract: We showed the history of the evolution of roller skate in the study entitled The History of Roller Skating $\mathrm{I}^{1}$., $\mathrm{II}^{2}$., $\mathrm{II}^{3}$. from the mid-1700s to the activities of the Olsen brothers. We deal with the roller skating life of the 1990s and the spread of motor roller skates and their types in this paper. We will introduce some new and exceptionally unique roller skate designs, which may become trend makers and represent the variety of the gear and of the form of movement. Finally, we will discuss the pop, film career of the roller skate in brief.

Keywords: skating, roller-skate, inline-skate, history

\section{AZ INLINE GÖRKORCSOLYA SPECIALIZÁLÓDÁSA}

1993-ban piacra kerül az agresszív, a terep (off-road) és a lesikló (down hill) inline görkorcsolya. Az egysoros gör-

\author{
10.21486/recreation.2013.3.3.2
}

korcsolyázás népszerüségének növekedése azonban egy időre megtorpant, amikor egyre nagyobb számban láttak napvilágot az esések utáni sérülésekröl szóló hírek. A leggyakoribb a csuklótörés és a fejsérülés volt. Természetesen a gyártók nem nyugodtak bele az egyébként valós veszélyeket rejtő sporteszköz eladási számainak csökkenésébe és különböző propagandaeszközökkel egyre erélyesebben próbálták rávenni a soros és párhuzamos görkorikat használó vásárlóikat, hogy sportolás közben viseljenek csukló-, könyök-, térd- és fejvédő felszerelést. Ezek a kiegészítö eszközök nagyban csökkentették a bukások okozta sérülések veszélyét és hasonló arányban növelték egy újabb piaci szelet részeként a bevételt. $A$ józanabbak hamar belátták, hogy a védőfelszerelés akár fitnesz, akár „műkorcsolyázás” közben felbecsülhetetlen szolgálatot tehet.

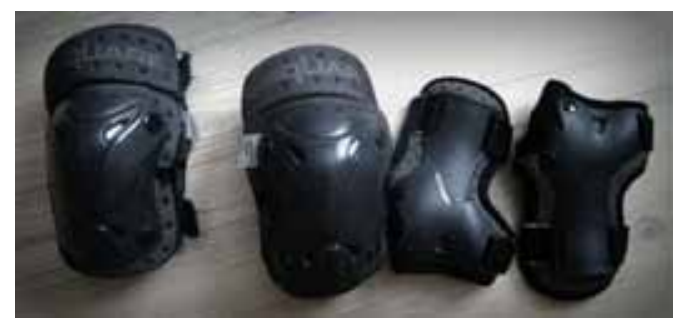

1. ábra Védőfelszerelések. Térd és csuklóvédő.

Természetesen csak idő kérdése volt, hogy a legjobb soros görkorisok hozzálássanak a sportág kereteinek átszabásához. Már nem elégítette ki őket, hogy civilizált módon ide-oda guruljanak a városban, ezért az aerobic-tól és a fitnesztől elszakadva új arculatot próbáltak kialakítani maguknak. Az új soros görkorcsolyázók a gördeszkásokhoz és a párhuzamos görkorcsolyásokhoz fordultak útmutatásért, nem csupán a kulturális alapozás kedvéért, hanem azért, hogy kilendítsék a sportágat a látszólagos holtpontról. Így a mozgalom kettészakadt, és kialakult az utcai, a rámpás, korlátokon, peremeken csúszkáló (street style) és a félcső (vert style) egysoros görkorcsolyázás.

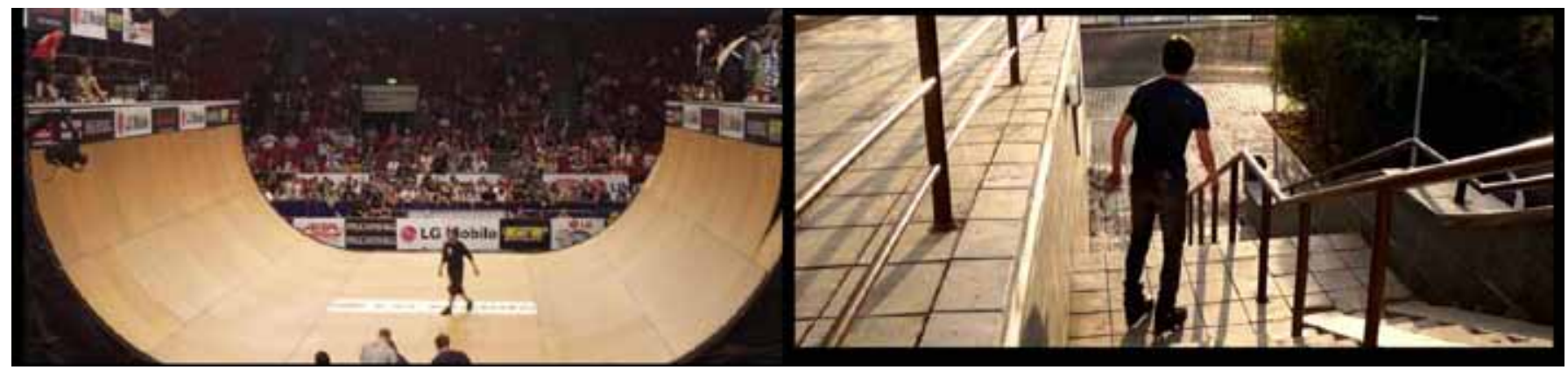

1 (Béres, A görkorcsolyázás története I., 2012)

2 (Béres, A görkorcsolyázás története II., 2012)

${ }^{3}$ (Béres , A görkorcsolyázás története III., 2013)

2. ábra A vert stlye (félcső) első kép ${ }^{4}$, és a street style (utcai) görkorcsolyázás - második kép.

${ }^{4}$ (Afterbang, 2013) 
A gördeszkásokhoz hasonlóan az utcai egysoros görkorcsolyázók elsődleges célja, hogy egészen elképesztő akadályokon ugráljanak át vagy csússzanak végig. Ehhez a görkori aljára különleges siklólemezeket szerelnek, hogy amikor nem kell, a kerekek ne akadjanak bele a felületbe, és a korcsolya alváza ne menjen tönkre az erős igénybevételtől. Ezek a szükségletek egy egész kiszolgáló iparágat hívtak életre, melynek feladata, hogy ellássa az egysoros görkorisokat a szükséges kiegészítökkel. A gyárak csak napjainkban kezdik felismerni, hogy ez a réteg jelenti a görkorcsolyázás jövőjét. Az egysoros görkorcsolyázással foglalkozó bármelyik folyóirat, például a Box vagy a Daily Bread lapjain minden létező kiegészítő megtalálható az extrém méretű könyökvédőtől, a pólókon át, a titánból készült korcsolya alvázakig. A siklólapok, egyedi alvázak, speciális kerekek és egyéb kellékek, melyeket régebben minden koris magának készített el, ma már postai csomagküldő cégektől is megrendelhetők.

A gördeszkások által jó három évtizeddel ezelőtt felderített terepen egy új városi sportág szerelmesei vették át az uralmat $A$ görkorcsolyások a gördeszkás stílus és kultúra jelentős részét beolvasztották a saját sportágukba, de a kezdetben csupán szabadidős sporteszköznek számító szerkezetet a pop-kultúra követői által is keblükre ölelt, igazi nagyvárosi „harci” járművé avatták.

A félcsövezés (vert) úgy kezdődött, hogy a legmerészebb soros görkorcsolyázók felmerészkedtek a gördeszkások mutatványainak helyszínére, a félbevágott csőhöz hasonló rámpára. Az invázió eleinte nem kevés feszültséget okozott a „görparkokban”. A helyzet csak azután normalizálódott, hogy a görkorcsolyázók egyre jobbak lettek, és mára kivívták a másik sportág mủvelőinek elismerését. A félcső görkorcsolyázás némileg eltér az ugyan ebben a közegben végzett gördeszkázástól, vagy BMX-ezéstől, mivel a koris két lába egymástól függetlenül, szabadon mozoghat. Napjaink legnagyobb hatású, független technikájú soros görkorcsolyázója az ausztrál TOM FRY. Képességeinek fényében átértékelődött a félcső görkorcsolyázás egésze, hiszen a sportág neki köszönheti a kizárólag az egysoros görkorcsolyázás sajátjának tekinthető trükköket.

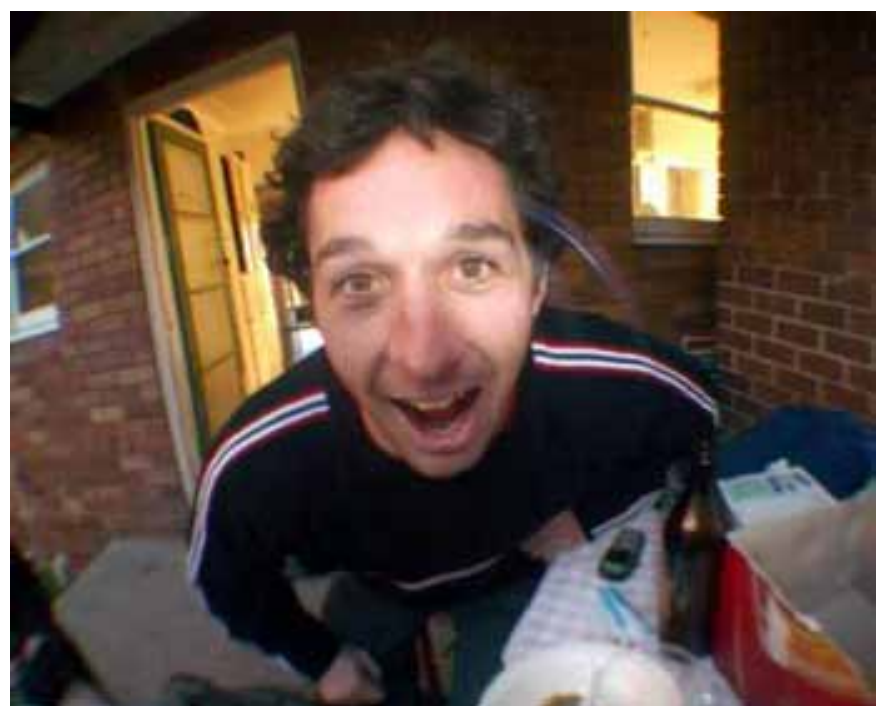

3. ábra Tom Fry sokszoros Ausztrál X Games (vert stlye) győztes görkorcsolyázó ${ }^{5}$ 1994-re tovább bővül a görkorisok amúgy sem kisszámú tábora. Az Egyesült Államok Sportszer Kereskedelmi Társaságának becslése szerint ekkorra már egyedül az államokban több mint 12 millió egysoros görkorcsolyás volt.

1995-ös adat alapján az USA-ban a görkorisok sérülései miatt a társadalombiztosításra kiadott összeg 2 milliárd dollárra emelkedett. Jelenleg közel 22 millió görkoris van Amerikában és 4,5 millió Németországban. Általános arányszám, hogy 1989 óta 500\%-os növekedés jellemzi a fogyasztói piacokat.

Az amerikai Nemzeti Görkorcsolya Múzeum honlapja $^{6}$ a görkorcsolya történeti áttekintésében a 90-es évekből a következő hasznos amerikai vonatkozású évszámokat jelenteti meg. 1991-ben indítják útjára az agresszív kori elkötelezett híveinek magazinját az Inline-t. 1992-ben az Amerikai Egyesült Államok gyorsasági görkorcsolya ágazata két divízióra bomlik, a quad és az egysoros ágazatra. 1995-ben az agresszív egysoros korcsolyát, mint új ágazatot felveszik az X-Games játékok közé, de tíz év után 2005-ben eltávolítják a játékokból. 1996-ban az USA Roller Skating ${ }^{7}$ görkorcsolya szervezet elöször sorolja külön osztályba az egysoros görtánc versenyeket (artistic skating). 1997-ben az egysoros görkorcsolyák és a hozzá való kiegészítők üzlete ezermillió dolláros iparágazattá válik, közel 26 millió amerikai részvételével. 1999-ben az egysoros hockey, Pan Amerikai Játékok elnevezéssel Kanadában tartják.

\section{SZÖVETSÉGEK MEGALAKULÁSA ${ }^{8}$}

A görkorcsolyázás története címü cikk csoportunkban fontosnak tartjuk röviden bemutatni a görkorcsolyával foglalkozó hivatalos szervezetek fajtáit ill. kialakulásuk történetét. A bemutatásban elsősorban a jelentős nemzetközi és magyar szervezetekre, intézményekre koncentráltunk.

1921-ben megalakult az Európai Görkorcsolyázó Szövetség (CERS - Confédération Européenne RollerSkating), melynek székhelye Róma. A szövetségnek három szakága van: a gyors-, a hoki- és a müvészi görkorcsolya. Mindhárom szakág űzhető hagyományos és soros görkorcsolyával is.

- 1924-ben megalakult a Nemzetközi Görkorcsolya Szövetség (FIRS - International Roller Skating Federation).

- $\quad$ 1980. október 27.-én alapítják meg a Nemzetközi Görkorcsolya Múzeumot.

- $\quad$ 1991-ben a legnagyobb inline görkorcsolyagyártók megalakították a Nemzetközi Inline Görkorcsolya Szövetséget (IISA), mely támogatja a sportolókat és a sportszervezést.

- A magyar görkorcsolyás élet legföbb hivatalos fóruma, a Magyar Országos Görkorcsolyázó Szövetség (MOGSZ) 1993 január 9-én Budapesten alakult, szombathelyi központtal, az Európai Szövetség 18. tagállamaként. - 1993 június 5-én szövetségünk felvételt nyert a

5 (Wikipedia, 2013)

${ }^{6}$ (National Museum of Roller Skating, 2010)

7 (USA Roller Skating, 2013)

8 (Béres, Görkorcsolyázás, 2004)

${ }^{9}$ (Acton, 2012) 
CERS soraiba. Jelenleg a CERS-nek 29 tagállama van, míg a Nemzetközi Görkorcsolyázó Szövetségnek (FIRS) 61 ország a tagja.

\section{MOTOROS GÖRKORCSOLYÁK}

\section{A SPINKIX ${ }^{9}$}

A görkorcsolyázás technikáját és magát az eszközt illetően jelentősen nem fejlődött az utolsó években. A következő, egyben talán utolsó lépés a görkorcsolya motorizálása, ugyanakkor ezzel a sajátos mozgásformát és ezen keresztül a speciális élettani hatásokat melyek ezzel járnak meg is szüntetik a tervezők. Marad a viszonylag szük körben való alkalmazhatóság, bár meg kell jegyezni, hogy az élvezeti érték ezért így is magas marad.

Pance (2011) így ír a motoros görkorcsolyáról. A gyaloglás a múlt századé. A helyes út a spn KiX motoros görkorcsolya, mellyel gyaloglás nélkül és körüljárhatja a környéket. A tervező Peter Treadway - írja Pance - úgy alakította ki azt az alkalmatosságot, hogy a használó, csak egyszerüen felkapja, mint egy cipőt, majd egy kézben tartott távirányítóval tudja szabályozni a sebességet. Az eszköz csúcssebessége körülbelül 10mérföld/óra, (16km/óra), melyet az akkumlátorral üzemeltetett motor, hozzávetőleg 3-5km-en keresztül képes tartani, mielőtt lemerül. Bár nem sok, ugyanakkor arra elég, hogy megsétáltassuk a kutyát, vagy elugorjunk a boltba. A lytiumion akksit ezután kb. 2 óráig kell tölteni.

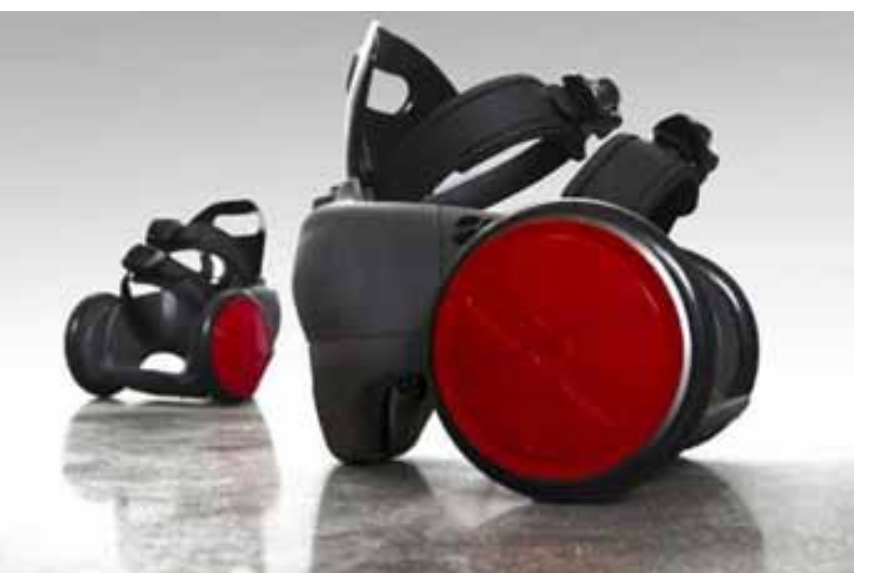

4. ábra A SpinKiX akumláttorról működő, elektomosmotorral hajtott görkorcsolya. Dizájner Peter Treadway.

Ennek a motoros görkorcsolyának eddig hozzávetőleg 30 prototípusa készült. Anyag nylon, alumínium. A cikk írásának időpontjában már a világpremierjére készülő korit, azóta (2012-ben), már bemutatták.

\section{ÚJ IRÁNYZATOK}

A görkorcsolya legújabb kori fejlődésének, vagy annak mellékágaként jegyezhető, a nem új keletü egykerekü (single-wheel „quintessence skate”) korcsolya, az 1988ban a kaliforniai Caples Lake Resort-ból való, MIYSHAEL F. GAILSON által tervezett és kivitelezett darab, melynek célja a sífutás ill. a telemark sízés modellezése ${ }^{10}$. A
Gailson görkorcsolyával való közlekedés módját a szerző honlapján található, általa bemutatott mozgás alapján sajátítható el (http://onewheelskate.tripod.com/).

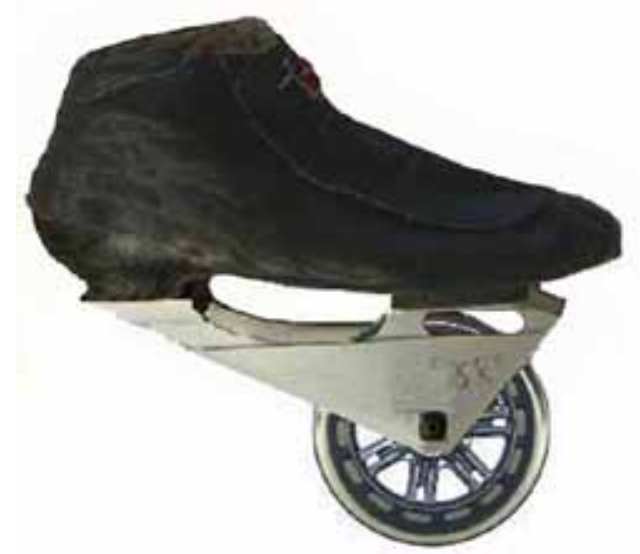

5. ábra A Gailson egykerekü korcsolya (Qsk8 2008)11

A görkorcsolya fejlesztési tendenciák a görkorcsolya technikai fejlődése iránt érdeklődő mérnök orosz blogger Mitskevichus (2011) szerint már nem annyira a hatékony müszaki fejlesztések határozzák meg, hanem sokkal inkább a cégek marketing politikája. Mindazonáltal elismeri, hogy az utolsó a görkorcsolyák technikai fejlesztése szempontjából két jelentősebb korszak az 1997-es év környéke amikor is a K2 kihozza a soft cipős korikat, de itt is főleg a moduláris struktúra kialakítása, melynek célja a korcsolyák jobb állíthatósága és lábra illeszthetőségének jelentős javítása. A szerző szerint a másik jelentős fejlődés 2006-ban történt, amikor SEBASTIEN LAFFARGUE mérnök kifejlesztette és forgalomba hozta a szlalom görkorcsolyákat.

\section{A LEGÚJABB IRÁNYZATOK - FREELINE SKATE}

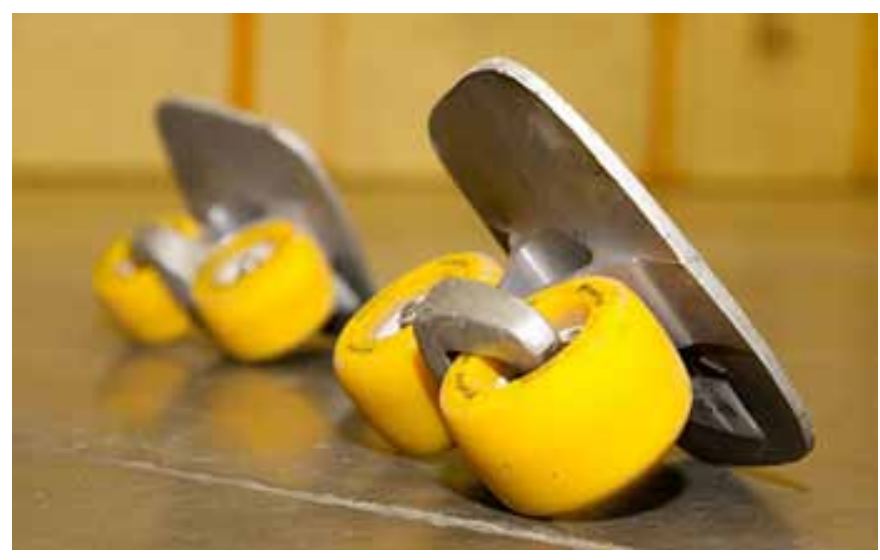

6. ábra A freeline skate két gördülő „talpa” (Forrás: ExBox)

A legújabb keletű gördülő sport a se nem görkorcsolya, se nem gördeszka Freeline Skate ${ }^{12}$. Mivel a konstrukció Magyarországon annyira új keletü, hogy a hivatalos magyar

${ }^{10}$ (Gailson, Gailson onewheelskate, 2013)

${ }_{11}$ (Gailson, Gailson onewheelskate, 2013)

${ }^{12}$ (Freeline Sports, 2010)

${ }^{13}$ (ExBlog, 2013) 
honlap, bár már regisztrált, de még nem müködik, ezért egy a témával kapcsolatos blogbejegyzésben értesülhetünk róla, hogy $\mathrm{mi}$ is ez az új sport ${ }^{13}$ :

„Mi az a Freeline Skates? Egy új (városi közlekedésre is kiváló) extrém sport, mely egyesítette a gördeszkázás, a snowboardozás, a szörfözés és a görkorcsolyázás élményét. A Freeline Skates debütálása óta sorra hódítja meg az országokat, és most hazánkba is elérkezett! Az eXboxban színvonalas pályán, profi oktatók segítségével sajátíthatod el a sport minden apró trükkjét. Ha még többet szeretnél megtudni a témáról, akkor kattints a Freeline Skates Hungary facebook oldalára."

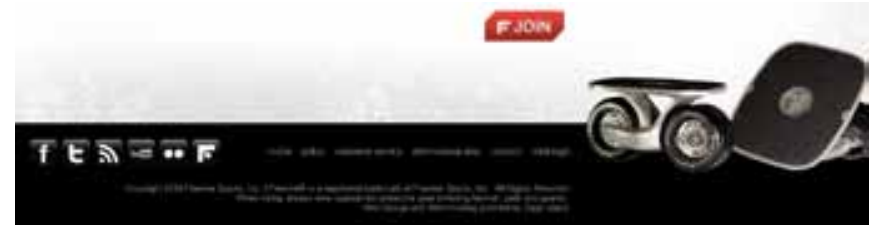

\section{ÚJABB TALÁLMÁNYOK A GÖRKORCSOLYÁZÁSBAN}

Talán a legújabb keletű találmány, amit még nem láthattunk az utakon a "safety - Edging Friction Contro/ TM 14" elnevezéssel illettek, mely szabad fordításban talán a „biztonsági - él-súrló kontrol”-ként említhetnénk, köznapi kifejezéssel farolást segítő. E 2005-ös találmány egy keréktengelybe épített rugós megoldás segítségével a kerekek oldal irányban elbillenhetnek, ami lehetővé teszi a görkorcsolyázónak, hogy megfelelő láberővel olyan a síelők és jégkorcsolyázók által alkalmazott fékezéseket is végre tudjanak hajtani, amire hagyományos görkorcsolya kerekekkel csak a legképzettebb profi görkorcsolyázók

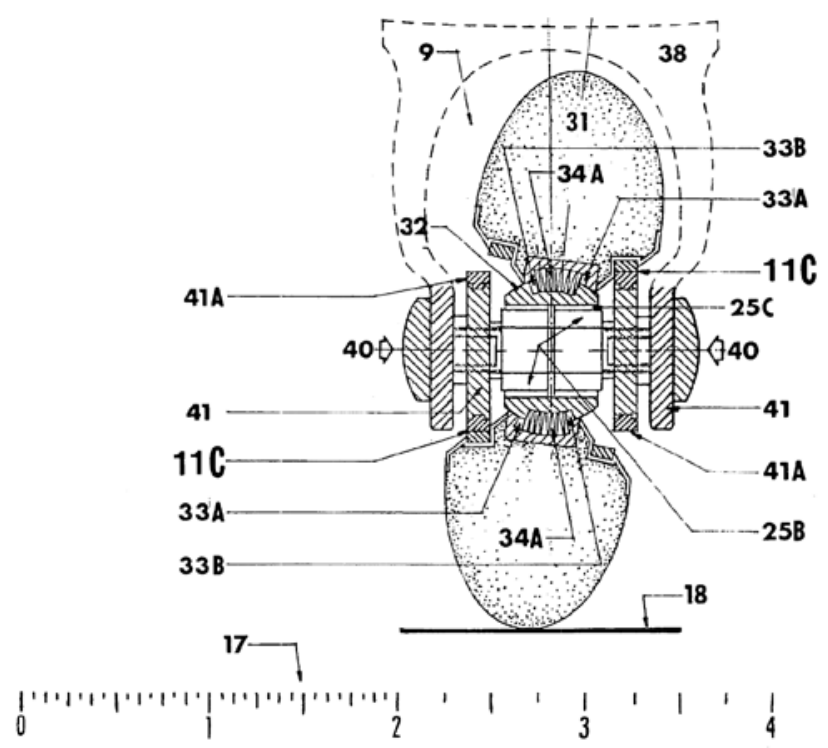

képesek, továbbá kiegyensúlyozottabbá teheti a fordulást.

7. ábra A Hurwitz (2005) féle a „biztonsági - él-súrló kontrol" - United States Patent 6848750

\footnotetext{
${ }^{14}$ (Hurwitz, 2005)

15 (IMDb, It's Always Fair Weather (Mindig szép az idő), 1955)

16 (Melanie, 2008)

17 (United Arists, 1979)

18 (IMDb, Xanadu, 1980)

19 (IMDb, Heaven's Gate (A mennyország kapuja), 1980)
}

\section{A GÖRKORCSOLYA A POPULÁRIS KULTÚRÁBAN}

1955 Gene Kelly görkorcsolyákat használ mint tánceszközöket az It's Always Fair Weather (Mindig szép az idő) c. filmben ${ }^{15}$.

1971 - a Brand New Key címú szám, melyet Melanie Safka ad elő, görkorcsolyákat használ témának ${ }^{16}$.

1979-es Roller Boogie címü musical Linda Blairrel és Jim Brayel a párhuzamos quad görkorcsolyákkal. A film nyitó képsora egy kerék beszereléssel és kevésbé szakszerü kenésével kezdődik. (E cikk megjelenésének pillanatában a teljes film elérhető a youtube-on is. ${ }^{17}$ )

1980-as Xanaduban - Olivia Newton-Johnnal a főszerepben - a görkorcsolya végig jelen van ${ }^{18}$.

1980-ban megjelenő A mennyország kapuja (Heaven's Gate) címü filmben, Christopher Walkennel a föszerepben, mely az 1890-es években játszódik Wyomingban, egy jelenetben megjelenik a korai görkorcsolya egy fajtája ${ }^{19}$.

1995-ös Ki az Úr a Háznál (Man of The House) címü filmben Jonatan Taylor Thomas egy korai Rollerblade modellel korizza körbe Seattle-t.

1998-ban a Disney Channel, Görmenők (Brink) címü filmje, egysoros görkorcsolyákkal történő tiniknek rendezett extrém versenyt mutat be $\mathrm{e}^{20}$.

2005-ös Roll Bounce (Kavaró korisok) című film fő cselekménye egy a késő 1970-es években zajlódó görkori verseny köré épül, ahol egy csapat tinédzser küzd egymással ${ }^{21}$.

2006-os ATL címü filmben, melyet Atlantában forgattak, a rapper T.I. és barátai főszereplésével, szintén megjelenik a görkorcsolyázás, mint alaptéma 22 .

2008 - az MTV Amerika Legjobb Tánc Csapata tehetségkutatójában feltünt egy tehetséges Hip Hop tánccsapat a Breaksk8, akik görkorcsolyával adták elő tudományukat.

2008 - a Seventies címü Laurent Wolf által előadott pop számban szerepel „Kim\&Jessie” az M83-asokból, két kori táncos. A szám a Youtubon is megtalálható Laurent Wolf Seventies (Official Music Video) címen ${ }^{23}$.

2009 a Whip It (Hajrá Bliss) című filmben Ellen Page és Drew Barrymore szereplésével (Barrymore rendezésében) - egy kisvárosi lány, csatlakozik egy női hard core roller derby csapathoz ${ }^{24}$.

2010 - a Skateland címü film - Shiloh Fernandez és Ashley Green főszereplésével - az 1980-as években játszódik, amikor a görkorizás rendkívül népszerű volt és a rengeteg tini járt korcsolya arénákba (roller rinks) ${ }^{25}$.
20 (IMDb, Brink (Görmenők), 1998)

21 (Port.hu, Roll Bounce (Kavaró korisok), 2005)

22 (IMDb, ATL (Görkorin az életbe), 2006)

${ }^{23}$ (Wolf, 2009)

${ }^{24}$ (Port.hu, Hajrá Bliss (Whip It), 2009)

25 (IMDb, Skateland, 2010) 


\section{IRODALOMJEGYZÉK}

Acton, I. (2012). SpinKix. Forrás: http://spnkix.com/: http://spnkix.com/

Afterbang. (2013). Afterbang Blog. Forrás: http://www. afterbang.co.uk: http://www.afterbang.co.uk/images/lg_ event/lg_vert_ramp.jpg

Béres, S. (2013. 02). A görkorcsolyázás története III. Rekreacio.eu(III/1), 27-33.

Béres, S. (2004). Görkorcsolyázás. Szeged, Csongrád megye, Magyarország: Szegedi Tud. Egy. Juhász Gyula Felsőoktatási Kiadó.

Béres, S. (2012. 09). A görkorcsolyázás története I. Recreatio.eu(II./3.).

Béres, S. (2012. 12). A görkorcsolyázás története II. (D. Erika, Szerk.) Recreacio.eu(II./4.), old.: 21.-27.

ExBlog. (2013). Freeline Skates. Forrás: http://www. exbox.hu: http://www.exbox.hu/?content=freeline skates

Freeline Sports, I. (2010). Freeline. Letöltés dátuma: 2013. 01 24, forrás: http://www.freelineskates.com/: http://www.freelineskates.com/

Gailson, M. F. (2013). Gailson onewheelskate. Letöltés dátuma: 2013. 01 22, forrás: http://onewheelskate. tripod.com/: http://onewheelskate.tripod.com/id1.html

Gailson, M. F. (2013). Gailson onewheelskate. Letöltés dátuma: 2013. 01 22, forrás: http://onewheelskate. tripod.com/: http://onewheelskate.tripod.com/ sitebuildercontent/sitebuilderpictures/qsk8_v_125_slvr_ rzr.jpg

Hurwitz, M. S. (2005). Generation of in-line skates and skate-boards with safety "edging friction control ${ }^{\mathrm{TM}}$ ". Letöltés dátuma: 2013. 08 26, forrás: http://www. freepatentsonline.com/: http://www.freepatentsonline. com/6848750.html

IMDb. (1955). It's Always Fair Weather (Mindig szép az idő). Letöltés dátuma: 2013. 01 24, forrás: http://www. imdb.com: http://www.imdb.com/title/tt0048216/

IMDb. (1980). Heaven's Gate (A mennyország kapuja). (Partisan Productions) Letöltés dátuma: 2013. 01 24, forrás: http://www.imdb.com: http://www.imdb.com/title/ tt0080855/?ref_=fn_al_tt_1

IMDb. (1980). Xanadu. Letöltés dátuma: 2013. 01 24, forrás: http://www.imdb.com: http://www.imdb.com/title/ tt0081777/?ref_=sr_1

IMDb. (1998). Brink (Görmenők). (Disney) Letöltés dátuma: 2013. 01 24, forrás: http://www.imdb.com: http:// www.imdb.com/title/tt0162212/

IMDb. (2006). ATL (Görkorin az életbe). (Warner Bros) Letöltés dátuma: 2013. 01 24, forrás: http://www.imdb. com: http://www.imdb.com/title/tt0466856/?ref_=fn_al_ tt_1

IMDb. (2010). Skateland. Letöltés dátuma: 2013. 0124 , forrás: http://www.imdb.com: http://www.imdb.com/title/ $\mathrm{tt}$ 1312254/?ref_=sr_1

Melanie.(2008.0130). Brand New Key, pair of roller skates. Letöltés dátuma: 2013. 01 24, forrás: http://youtube.com: http://www.youtube.com/watch?v=p02DgHeGdyl

National Museum of Roller Skating. (2010). The history of inline skating at the National Museum of Roller Skating. Letöltés dátuma: 2013. 01 24, forrás: http://www.rollerskatingmuseum.com: http://www. rollerskatingmuseum.com/inline.html

Ponce, D. (2011. 12 20). spnKiX, The Electric Rolling Shoe Things. Letöltés dátuma: 2013. 03, forrás: Oh Gizmo: http://www.ohgizmo.com/wp-content/uploads/2011/12/ spnKiX_red_1_610x458-500x375.jpg

Port.hu. (2005). Roll Bounce (Kavaró korisok). Letöltés dátuma: 2013. 01 24, forrás: port.hu: http://port.hu/ kavaro_korisok_roll_bounce/pls/fi/films.film_page?i_ topic_id=2\&i_film_id=85720\&i_city_id=-1\&i_county_id=-1 Port.hu. (2009). Hajrá Bliss (Whip It). Letöltés dátuma: 2013. 01 24, forrás: port.hu: http://port.hu/hajra_bliss!_ whip_it!/pls/fi/films.film_page?i_topic_id=2\&i_film_ id=106901\&i_city_id=-1\&i_county_id=-1

United Arists. (1979). ROLLER BOOGIE full movie Linda Blair Jim Bray 1979 disco skating. Letöltés dátuma: 2013. 01 23, forrás: http://www.youtube.com: http://www. youtube.com/watch?v=olCoGGQ6mAc

USA Roller Skating. (2013). USA Roller Skating. (at\&t) Letöltés dátuma: 2013. 01 28, forrás: http://www.teamusa. org/USA-Roller-Sports.aspx: http://www.teamusa.org/ USA-Roller-Sports.aspx

Wikipedia. (2013. 05). Tom Fry. Letöltés dátuma: 2013. 08 26, forrás: Wikipedia: http://en.wikipedia.org/wiki/ Tom_Fry

Wolf, L. (2009. 01 05). Laurent Wolf - Seventies (Official Music Video). Letöltés dátuma: 2013. 01 24, forrás: http://www.youtube.com: http://www.youtube.com/ 